\title{
FORMAÇÄO, PRAXIS E INTERESSES SEXUAIS DO GRADUANDO EM ENFERMAGEM: PESQUISA PARTICIPANTE COMO PROCESSO EDUCATIVO
}

\author{
Moneda Oliveira Ribeiro*
}

\section{NOTA PRÉVIA}

RIBEIRO, M.O. Formação, praxis e interesses sexuais do graduando em enfermagem: pesquisa participante como processo educativo. Nota prévia. Rev. Esc. Enf. USP, São Paulo, 20(3):273, 1986.

A autora tensiona obter subsídios que lhe possibilitem compreender a formação, praxis e interesses sexuais do graduando em enfermagem.

Devido ao caráter educativo do tema proposto, e por entender a educação como sendo um processo de conscientização que visa a solução de problemas, a autora optou pela pesquisa participante (abordagem qualitativa concernente ao método dialético do materialismo histórico).

$O$ estudo encontra-se em fase de coleta de dados.

\section{NURSING STUDANTS' SEXUAL FORMATION, PRAXIS AND INTERESTS: PARTICIPANT RESEARCH AS AN EDUCATE PROCESS}

RIBEIRO, M.O. Nursing students' sexual formation, praxis and interests: participant research as an educative process. Rev. Esc. Enf. USP, São Paulo, 20(3):273, 1986.

The author intends to obtain subsidies to understand the nursing studants' information, praxis and interests in sex.

Due to the educacional character of the proposed theme and understanding education as a process by which one will become conscious of the solution of problems, the author decided to develop her study by the dialectic method of Marx's doctrine.

The study is in the data collection phase.

\footnotetext{
* Enfermeira. Auxiliar de Ensino do Departamento de Enfermagem Materno-Infantil e Psiquiátrica da Escola de Enfermagem da USP - disciplina Enfermagem Pediátrica.
} 